\title{
Optimal Category Mix in Multi-Category Retailing - Insights from an Experiment
}

\author{
H. R. Ganesha ${ }^{1}$, P. S. Aithal ${ }^{2}$, \& P. Kirubadevi ${ }^{3}$ \\ ${ }^{1}$ Chief Executive Officer - Consulting Division, Gramss Retail Trading Private Limited, \\ Bengaluru - 560078, India and Post-Doctoral Research Fellow, College of Management \& \\ Commerce, Srinivas University, Mangalore - 575001, India. \\ OrcidID: 0000-0002-5878-8844; E-mail: hrganesha@yahoo.co.in \\ ${ }^{2}$ Vice Chancellor, Srinivas University, Mangalore - 575001, India. \\ OrcidID: 0000-0002-4691-8736; \\ E-mail: psaithal@gmail.com \\ ${ }^{3}$ Head of Category Management and Sourcing, Actoserba Active Wholesale Private Limited \\ (Zivame), Bengaluru - 560038, India. \\ OrcidID: 0000-0003-2291-8448; E-mail: spkirubadevi@yahoo.com
}

Area of the Paper: Business Management.

Type of the Paper: Experimental Analysis.

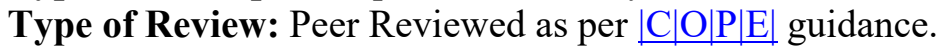

Indexed In: OpenAIRE.

DOI: http://doi.org/10.5281/zenodo.3822483.

Google Scholar Citation: IJCSBE.

\section{How to Cite this Paper:}

Ganesha, H. R., Aithal, P. S. \& Kirubadevi, P. (2020). Optimal Category Mix in Multi-Category Retailing - Insights from an Experiment. International Journal of Case Studies in Business, IT, and Education (IJCSBE), 4(1), 112-126. DOI: http://doi.org/10.5281/zenodo.3822483.

International Journal of Case Studies in Business, IT and Education (IJCSBE)

A Refereed International Journal of Srinivas University, India.

(C) With Authors.

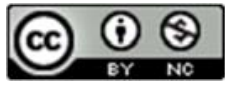

This work is licensed under a Creative Commons Attribution-Non-Commercial 4.0 International License subject to proper citation to the publication source of the work.

Disclaimer: The scholarly papers as reviewed and published by the Srinivas Publications (S.P.), India are the views and opinions of their respective authors and are not the views or opinions of the S.P. The S.P. disclaims of any harm or loss caused due to the published content to any party. 


\title{
Optimal Category Mix in Multi-Category Retailing - Insights from an Experiment
}

\author{
H. R. Ganesha ${ }^{1}$, P. S. Aithal ${ }^{2}$, \& P. Kirubadevi ${ }^{3}$ \\ ${ }^{1}$ Chief Executive Officer - Consulting Division, Gramss Retail Trading Private Limited, \\ Bengaluru - 560078, India and Post-Doctoral Research Fellow, College of Management \& \\ Commerce, Srinivas University, Mangalore - 575001, India. \\ OrcidID: 0000-0002-5878-8844; E-mail: hrganesha@yahoo.co.in \\ ${ }^{2}$ Vice Chancellor, Srinivas University, Mangalore - 575001, India. \\ OrcidID: 0000-0002-4691-8736; \\ E-mail: psaithal@gmail.com \\ ${ }^{3}$ Head of Category Management and Sourcing, Actoserba Active Wholesale Private Limited \\ (Zivame), Bengaluru - 560038, India. \\ OrcidID: 0000-0003-2291-8448; E-mail: spkirubadevi@yahoo.com
}

\begin{abstract}
In brick-and-mortar retailing format, retailers need to ensure minimum level of inventory displayed at each store for each category irrespective of the revenue or profit generated by a particular category. It is observed that majority of bricks-and-mortar retailers in India assume; (a) existing category mix is ideal for their stores, (b) any modification in the existing category mix could possibly lead to loss of sale of an existing category, (c) it is preferred to have categories generating higher average transaction values and most importantly,(d) categories with lower average selling price products and generating lower average transaction values negatively impact store's revenue. Such assumptions and widely followed practice have created a predisposition and mindset in store managers and they believe that, their store delivers revenue and profit to the best of its potential with the existing category mix. In this research, we have analysed the existing category mix of a select retailer, attempted to alter the existing category mix through an experiment and evaluated change in (a) category level profitability, and (b) overall store profitability.
\end{abstract}

Keywords: Brick-and-mortar store; Offline store; Physical store; Multi-Category; Category Mix; Category Management; FMCG; Hardlines; Softline.

\section{INTRODUCTION :}

Inventory is one of the most important costs in retailing which holds significant share of overall retailing cost structure. Even though inventory cost is variable in nature, due to its carrying cost inventory becomes even more important aspect of retailing which has direct impact on cash flow efficiency and retail profitability. Multi-category and multi-branded retail stores catering to multiple life-stage needs of a consumer comprise of many categories which are designed to serve specific needs of consumers. Most of the retailers, classify these products into different sections either based on consumer needs (demand side) or product's behaviour (supply side) or visual appeal (communication side) or consumer life-stage (solution side) and this classification is known as categories. Each of these categories include multiple sub-categories and each sub-category is comprised of multiple brands, models, colours and SKUs. Usually retailers categorise all the products which are predominantly made up of textile base in to Softline such as Apparels, products which are not predominantly made up of textile base are categorised as Hardlines such as Furnitures and products which are basic need of consumers and required by them for frequent usage are categorised as FMCG (fast moving consumer goods) such as non-durable household items. Every category in the storeplays an important role with respect to consumer and retailer. It is imperative to note that, understanding of the role played by a

H. R. Ganesha, et al. (2020); www.srinivaspublication.com

PAGE 113 
particular category might not be same among consumers, retailers and sales personnel, what is really important and of significant essence is that, every employee in the retailing business whether belonging to central office or store is familiar with each of these category roles in relation to consumers' needs and align their category mix in the merchandise assortment which could possibly help the retailer to enhance optimal utilization of every category thereby enhancing; (a) consumer store visits frequency, (b) consumer retention rate, and (c) overall store profitability along with efficient cash-flow. Unfortunately, it is not possible for retailer to have a perfect/ideal/standard category mix suitable for every store spread across many locations/sizes. For many years it has been debated among retailing management researchers about, what is the ideal category mix, which category yields the best store profit, which category should be focussed and pushed to consumers. Few have suggested to make use of software tools and solutions and others have recommended to adopt different techniques available in category management.

\section{LITERATURE REVIEW :}

Lindquist (1974) [1], was the first to list the key components of store image construct. Based on past studies Lindquist listed eight component of store image construct viz., (i) merchandise, (ii) clientele, (iii) physical facilities, (iv) convenience, (v) promotion, (vi) store atmosphere, (vii) institutional factors, and (viii) post-transactional satisfaction. Hirschman et, al. (1978) [2] have later confirmed that the basic attributes of store image construct as listed by Lindquist in 1974 remain unchanged. Ghosh (1994) [3], through his studies was able add few more attributes to store image construct such as ix) customer service, x) personal selling and xi) sales incentive programs. Omar (1999) [4], argues that these factors together influence the overall store image in consumers mind only when the consumers have experienced these factors through actual shopping. There have been many studies confirming positive correlation between store layout and consumer loyalty (Mazursky and Jacoby (1986) [5], Osman (1993) [6] and Lassk (2000) [7]. As per Newman and Cullen (2002) [8], consumers perception of store image varies with store layout. Consumers shopping at different store formats having different store layouts create their own perception of store image in their mind. Newman (2003) [9], extends this study and recommends bricks-and-mortar retailers to align their store layout design keeping their target consumers in mind rather adopting standard layout designs. Lilien et, al. (1995) [10], argues that retailers need to consider various location specific factors while planning for expansion such as (a) attractiveness of the market, (b) number of stores to be opened per market, (c) store locations, and (d) ideal store size for each of these stores. In this study they clearly indicate that, every store needs to have size optimal for the location and market it is present rather a standard size being adopted across all the stores of a particular retailing format. In all these studies nowhere, researchers recommend retailers to adopt different price level of merchandise for different locations of stores.

Salmon (1989) [11] argues that it is no more just merchandising, which is important for successful retailing, what is becoming more and more important now a days is other aspects of store operations which includes various other aspects including inventory management. Raman et, a. (2001) [12], in their study reported that the accuracy level of inventory available in the store is significantly poor and this was attributed to issues with inventory replenishment systems and inventory planning methodology. Wanger (2002) [13] argues that because of various data related issues including inventory accuracy levels, many fail to implement the automated replenishment system and strongly recommends that different replenishment tools must be applied in relation to real-time inventory issues. James L. Hesket et al. (1997) [14], argues that the profitability is significantly derived from consumer loyalty which is strongly linked to (a) internal service quality and (b) satisfied and productive service employee. The service-profit chain model created in their work holds true even after globalization, liberalization and digitization of retail market. Inventory cannot treat as one of the key aspects of retailing in isolation. The mix, level and type of inventory also impact the satisfaction and productivity levels of sales personnel which in turn impact the consumer loyalty towards store.

In the past, various indicators which can indicate a retail sale in relation to quality and level of sales personnel involvement have been studied and analysed by many researchers. Most important indicators were a) the amount and quality of time spent by the sales personnel with the consumer (Davis. H.L. et al. (1972) [15]), (b) variety of products/SKUs/models being showcased by the sales personnel to consumer (Dawson et al. (1992) [16]), (c) level of information being collected by the sales personnel 
on consumer needs directly from the consumer (Sharma. A. (2001) [17]), (d) sales personal's efforts to understand the consumer brand preference and showcasing products/SKUs/models in relation to the preference (Pettijohn. C.E. et al. (2002) [18], (e) sales personnel's capability to explain the features of products showcased to consumers and their confidence level while explaining the differentiation among variety of products showcased (Aggarwal. P. et al (2005) [19]) and (f) the range of products/SKUs/models showcased by the sales personnel in relation to price and utility expected by the consumer (Davis. D. D. (2008) [20]). All these findings are affirmative to the fact that the sales personnel's engagement with consumer in real-time significantly influence consumer's purchase decision directly and it is imperative that the category being focussed and pushed by sales personnel to consumers is being driven keeping consumer repeat visit frequency and retention rate as the key goal.

Ainslie and Rossi (1998) [21] by analysing multiple categories have demonstrated that there is a significant correlation between display and the sensitivity of FMCG products. FMCG products by their nature have low purchase involvement and purchase decisions are being made by consumers in real-time inside a store, it is very important to have proper selling and showcasing strategy. In-store display of such products which can create high consumer repeat visit rate becomes very crucial to draw consumer attention to these FMCG products (Hoyer (1984) [22]; Drèze, Hoch, and Purk (1994) [23]; Chandon et al. (2007) [24]).

In the available empirical, theoretical and descriptive literature we were not able to find significant literature which guides brick-and-mortar retailers with respect to ideal category mix in their stores with which we could answer our research questions such as (a) should we believe that the existing category mix available at stores in different locations having different sizes is appropriate?,(b) should we believe that the existing category mix is delivering optimal store revenue and profit?, (c) should we believe that the existing category mix strategy is aligned to retailer's target consumers? or (d) is it a misconception among retailers that category mix must be skewed towards categories which have higher selling prices and generate higher transaction values?. Thus, we decided to select a national retailer, understand their existing category mix strategy among their stores spread across different locations and vary in retailing size, empirically evaluate the actual sales data in relation to category mix and overall store profitability, change the existing category mix through an experiment and draw insights to recommend brick-and-mortar retailers the right strategy of category mix to gain long-term strategic and competitive advantage.

\section{OBJECTIVES :}

Key objectives of this research were to;

(a) by changing the existing category mix understand the change in;

i. bills/invoices

ii. quantity

iii. revenue

iv. cost of goods sold

v. earning

vi. category profitability

vii. store profitability

(b) draw insights from the analysis and recommend an optimal categorymix for multi-category retailing.

\section{METHODOLOGY :}

Stage I: One of the organized brick-and-mortar retailers in India was selected who is having stores all over India across (a) high street stores, (b) mall stores, (c) institutional stores, (d) tier 1, 2 and 3 cities, offering multiple-categories and multiple-brands serving different consumer life-stage needs at mid to high price positioning and catering to pregnant women, new moms, babies, infants and kids up to 8 years. 10 percent of stores were exposed to experiment and others were not.

Stage II: Store wise and category wise actual sales data of previous six months was collected (pre-test period). 
Stage III: Exploratory open-ended direct interview was conducted with randomly selected (convenience sampling) employees belonging to select retailer representing all the departments and functions to understand their perspective and attitude towards contribution of each category to overall store performance.

Stage IV: Experimental stores were exposed to experiment for six months.

Stage V: Post-test primary data was collected and analysed using appropriate statistical methods.

Stage VI: In this stage, insights and inferences from the research findings were used to recommend optimal category mix for multi-category bricks-and-mortar retailing.

\section{EXPERIMENT :}

During the direct interview with store team and central teams managing category, retail planning, marketing, supply chain, finance and strategy we have noted that; majority of members strongly believed that;

(a) Hardlines category generates larger average transaction values per bills, most of the products in Hardlines category are high priced and sales personnel are motivated to push these items to consumers, Hardlines category contributes almost equivalent revenue as compared to Softlines category with significantly lesser quantity sale contribution;

(b) Softline category generates highest revenue for the store with healthy earning percentage, it is easier to sell Softline category products as consumers have better awareness;

(c) consumers buy FMCG products belonging to trusted brands and they are also being sold in many other retailing formats, FMCG category generates lowest average transaction values, average selling price of FMCG items is the lowest and hence sales personnel do not push these items to consumers, FMCG category has the lowest earning percentage and thus it is difficult to offer higher discounts to consumers on this category and most importantly;

(d) allocating larger space to Hardlines and Softline categories generate higher overall store revenue.

In contrary to what retailer believed, while analysing pre-test sales data, we have found that; (a) Hardlines category generates significant losses for the store;(b) Softline category generates moderate profits for the store;(c) FMCG category has a break even sale and in fact the biggest contributor to overall store bills/invoices being generated.

Based on all these insights we decided to carry out an experiment spread over a period of six months, wherein we have;

(a) increased the stock mix of FMCG category products by 20 percent through improved display density without making any changes in the FMCG category area mix,

(b) given additional incentives to sales personnel to push FMCG category to consumers which was based on number of units being sold and not based on revenue being generated,

(c) allowed stores to increase the discount by 5 percentage points on an annualized basis for all the FMCG products in the store,

(d) increased number of in-store promotional signages for FMCG category,

(e) conveyed existing consumers about promotions and offers specific to FMCG category through regular communication via SMS and

(f) involved external brand's representatives to support in supplying relevant promotional creatives for in-store signages.

Sales personnel and the store management team were trained for a period of thirty days prior to experimentation wherein, they were explained about;

(a) each and every product in the FMCG category

(b) each and every brand in the FMCG category

(c) features, benefits and differences among different FMCG products and brands

(d) FMCG category consumers' purchase pattern vis-à-vis other categories

(e) store visit frequency pattern of FMCG consumers vis-à-vis other categories

(f) cross-category purchase patterns of FMCG consumers 


\section{KEY FINDINGS AND INSIGHTS :}

Using pre-test post-test real treatment effect formula, we have found that the real treatment effect has shown a 164.36 percent improvement in the overall store profitability of experimental group as shown in table 1;about 111.41 percent improvement in FMCG category profit as shown in table 2;about 49.31 percent deterioration in Hardlines category profit as shown in table 3; and a 68.08 percent improvement in Softline category profit as shown in table 4over their pre-test period. Real treatment effect for every other key factors is also shown in table 1,2,3 and 4.Comparative results as shown in table 5, 6, 7, 8 and 9 when compared with different phases and groups indicate that in the experimental group of stores an increase of 19.61 percent in the FMCG category mix and 4.96 percentage points increase in discount has shown 218.75 percent improvement in overall store profitability without any reduction in the overall store revenue in spite of FMCG category's average transaction value per bill/invoice being 121.40 percent lower than Hardlines and 64.16 percent lower than Softline categories.

Table 1: Pre-test post-test real treatment effect across key factors in experimental group as percentage change over their pre-test period.

\begin{tabular}{|l|c|}
\hline Factors & $\begin{array}{c}\text { Post-Test } \\
\text { Experimental } \\
\text { Group }\end{array}$ \\
\hline Average MRP & $-1.0 \%$ \\
\hline Average Selling Price & $-4.4 \%$ \\
\hline Average Cost Price & $-3.7 \%$ \\
\hline Average Earning Value & $-2.9 \%$ \\
\hline Average Basket Size & $1.0 \%$ \\
\hline Average Transaction Value & $-2.5 \%$ \\
\hline Discount per cent & $19.8 \%$ \\
\hline Bills per square foot & $34.5 \%$ \\
\hline Quantity per square foot & $31.0 \%$ \\
\hline Revenue per square foot & $31.4 \%$ \\
\hline COGS persquare foot & $35.2 \%$ \\
\hline Eam ing per square foot & $34.4 \%$ \\
\hline Store profit per square foot & $164.36 \%$ \\
\hline Contribution to retailer bills & $56.4 \%$ \\
\hline Contribution to retailer quantity sale & $57.8 \%$ \\
\hline Contribution to retailer revenue & $52.7 \%$ \\
\hline Contribution to store COGS & $57.1 \%$ \\
\hline Contribution to retailer eam ings & $57.5 \%$ \\
\hline
\end{tabular}

Table 2: Pre-test post-test real treatment effect across key factors in experimental group FMCG category as percentage change over their pre-test period.

\begin{tabular}{|l|c|}
\hline Factors & $\begin{array}{c}\text { Post-Test } \\
\text { Experimental } \\
\text { Group }\end{array}$ \\
\hline FMCG
\end{tabular}


Table 3: Pre-test post-test real treatment effect across key factors in experimental group Hardlines category as percentage change over their pre-test period.

\begin{tabular}{|l|c|}
\hline Factors & $\begin{array}{c}\text { Post-Test } \\
\text { Experimental } \\
\text { Group } \\
\text { Hardlines }\end{array}$ \\
\hline Average MRP & $-2.9 \%$ \\
\hline Average Selling Price & $-5.3 \%$ \\
\hline Average Cost Price & $-5.7 \%$ \\
\hline Average Earning Value & $-5.2 \%$ \\
\hline Average Basket Size & $-0.4 \%$ \\
\hline Average Transaction Value & $-3.1 \%$ \\
\hline Dis count per cent & $8.5 \%$ \\
\hline Bills per square foot & $31.8 \%$ \\
\hline Quantity per square foot & $27.2 \%$ \\
\hline Revenue per square foot & $23.9 \%$ \\
\hline COGS per square foot & $25.5 \%$ \\
\hline Eaming per square foot & $29.5 \%$ \\
\hline Category profit per square foot & $-49.31 \%$ \\
\hline Contribution to store bills & $3.4 \%$ \\
\hline Contribution to store quantity sale & $1.7 \%$ \\
\hline Contribution to store revenue & $2.8 \%$ \\
\hline Contribution to store COGS & $1.3 \%$ \\
\hline Contribution to store eam ings & $3.0 \%$ \\
\hline
\end{tabular}

Table 4: Pre-test post-test real treatment effect across key factors in experimental group Softline category as percentage change over their pre-test period.

\begin{tabular}{|l|c|}
\hline Factors & $\begin{array}{c}\text { Post-Test } \\
\text { Experimental } \\
\text { Group } \\
\text { Softlines }\end{array}$ \\
\hline Average MRP & $-0.7 \%$ \\
\hline Average Selling Price & $-6.9 \%$ \\
\hline Average Cost Price & $-4.9 \%$ \\
\hline Average Earning Value & $-2.9 \%$ \\
\hline Average Basket Size & $3.2 \%$ \\
\hline Average Transaction Value & $-3.8 \%$ \\
\hline Discount per cent & $51.4 \%$ \\
\hline Bills per square foot & $19.4 \%$ \\
\hline Quantity per square foot & $21.8 \%$ \\
\hline Revenue per square foot & $15.7 \%$ \\
\hline CoGS per square foot & $17.5 \%$ \\
\hline Eaming persquare foot & $20.5 \%$ \\
\hline Category profit per square foot & $68.08 \%$ \\
\hline Contribution to store bills & $-5.3 \%$ \\
\hline Contribution to store quantity sale & $-3.0 \%$ \\
\hline Contribution to store revenue & $-6.7 \%$ \\
\hline Contribution to store COGS & $-6.7 \%$ \\
\hline Contribution to store eam ings & $-5.0 \%$ \\
\hline
\end{tabular}


Table 5: Percentage variance between experimental group and control group across key factors in pre and post-test periods.

\begin{tabular}{|l|c|c|}
\hline Factors & $\begin{array}{c}\text { Pre-Test } \\
\text { Experimental } \\
\text { Group }\end{array}$ & $\begin{array}{c}\text { Post-Test } \\
\text { Experimental } \\
\text { Group }\end{array}$ \\
\hline Average MRP & $-20.4 \%$ & $-21.0 \%$ \\
\hline Average Selling Price & $-16.7 \%$ & $-19.5 \%$ \\
\hline Average Cost Price & $-16.7 \%$ & $-18.7 \%$ \\
\hline Average Earning Value & $-18.0 \%$ & $-18.8 \%$ \\
\hline Average Basket Size & $-5.5 \%$ & $-4.8 \%$ \\
\hline Average Transaction Value & $-18.9 \%$ & $-21.0 \%$ \\
\hline Discount per cent & $-2.8 \%$ & $14.9 \%$ \\
\hline Bills per square foot & $41.6 \%$ & $76.6 \%$ \\
\hline Quantity per square foot & $31.2 \%$ & $63.0 \%$ \\
\hline Revenue per square foot & $20.3 \%$ & $49.0 \%$ \\
\hline COGS persquare foot & $20.1 \%$ & $51.6 \%$ \\
\hline Eaming per square foot & $20.4 \%$ & $52.3 \%$ \\
\hline Store profit per square foot & $\mathbf{4 8 7 . 6 \%}$ & $\mathbf{3 4 6 . 4} \%$ \\
\hline
\end{tabular}

Table 6: Percentage variance between experimental group and control group across key factors in pre and post-test periods for FMCG category.

\begin{tabular}{|l|c|c|}
\hline Factors & $\begin{array}{c}\text { Pre-Test } \\
\text { Experimental } \\
\text { Group } \\
\text { FMCG }\end{array}$ & $\begin{array}{c}\text { Post-Test } \\
\text { Experimental } \\
\text { Group } \\
\text { FMCG }\end{array}$ \\
\hline Average MRP & $-14.3 \%$ & $-10.9 \%$ \\
\hline Average Selling Price & $-6.9 \%$ & $-4.5 \%$ \\
\hline Average Cost Price & $-6.6 \%$ & $-2.8 \%$ \\
\hline Average Earning Value & $-5.5 \%$ & $0.6 \%$ \\
\hline Average Basket Size & $-8.3 \%$ & $-8.8 \%$ \\
\hline Average Trans action Value & $-14.5 \%$ & $-12.9 \%$ \\
\hline Discount per cent & $11.3 \%$ & $25.6 \%$ \\
\hline Bills per square foot & $40.5 \%$ & $78.1 \%$ \\
\hline Quantity per square foot & $28.9 \%$ & $62.1 \%$ \\
\hline Revenue per square foot & $19.8 \%$ & $55.0 \%$ \\
\hline COGS per square foot & $20.2 \%$ & $57.7 \%$ \\
\hline Eaming per square foot & $21.6 \%$ & $63.4 \%$ \\
\hline Category profit per square foot & $70.4 \%$ & $\mathbf{1 5 0 . 8} \%$ \\
\hline Contribution to store bills & $-1.6 \%$ & $2.1 \%$ \\
\hline Contribution to store quantity sale & $-3.4 \%$ & $-0.9 \%$ \\
\hline Contribution to store revenue & $-1.1 \%$ & $6.9 \%$ \\
\hline Contribution to store COGS & $-0.3 \%$ & $7.4 \%$ \\
\hline Contribution to store eamings & $0.9 \%$ & $10.9 \%$ \\
\hline
\end{tabular}


Table 7: Percentage variance between experimental group and control group across key factors in pre and post-test periods for Hardlines category.

\begin{tabular}{|l|c|c|}
\hline Factors & $\begin{array}{c}\text { Pre-Test } \\
\text { Experimental } \\
\text { Group } \\
\text { Hardlines }\end{array}$ & $\begin{array}{c}\text { Post-Test } \\
\text { Experimental } \\
\text { Group } \\
\text { Hardlines }\end{array}$ \\
\hline Average MRP & $-26.8 \%$ & $-28.8 \%$ \\
\hline Average Selling Price & $-24.8 \%$ & $-27.8 \%$ \\
\hline Average Cost Price & $-24.2 \%$ & $-26.8 \%$ \\
\hline Average Earning Vahe & $-27.1 \%$ & $-27.9 \%$ \\
\hline Average Basket Size & $-1.3 \%$ & $-1.8 \%$ \\
\hline Average Transaction Value & $-25.8 \%$ & $-28.9 \%$ \\
\hline Discount per cent & $-2.4 \%$ & $4.8 \%$ \\
\hline Bills per square foot & $48.3 \%$ & $88.5 \%$ \\
\hline Quantity per square foot & $46.5 \%$ & $84.9 \%$ \\
\hline Revenue per square foot & $10.0 \%$ & $34.5 \%$ \\
\hline COGS per square foot & $10.9 \%$ & $36.3 \%$ \\
\hline Eaming per square foot & $6.7 \%$ & $34.1 \%$ \\
\hline Category profit per square foot & $-6.3 \%$ & $-55.1 \%$ \\
\hline Contribution to store bills & $4.1 \%$ & $8.1 \%$ \\
\hline Contribution to store quantity sale & $10.1 \%$ & $13.0 \%$ \\
\hline Contribution to store revenue & $-9.2 \%$ & $-7.2 \%$ \\
\hline Contribution to store COGS & $-7.9 \%$ & $-7.2 \%$ \\
\hline Contribution to store eam ings & $-11.4 \%$ & $-8.9 \%$ \\
\hline
\end{tabular}

Table 8: Percentage variance between experimental group and control group across key factors in pre and post-test periods for Softline category.

\begin{tabular}{|l|c|c|}
\hline Factors & $\begin{array}{c}\text { Pre-Test } \\
\text { Experimental } \\
\text { Group } \\
\text { Softlines }\end{array}$ & $\begin{array}{c}\text { Post-Test } \\
\text { Experimental } \\
\text { Group } \\
\text { Softlines }\end{array}$ \\
\hline Average MRP & $-11.6 \%$ & $-12.2 \%$ \\
\hline Average Selling Price & $-3.9 \%$ & $-9.9 \%$ \\
\hline Average Cost Price & $-5.1 \%$ & $-9.4 \%$ \\
\hline Average Earning Vahe & $-5.4 \%$ & $-7.7 \%$ \\
\hline Average Basket Size & $-6.0 \%$ & $-3.0 \%$ \\
\hline Average Transaction Value & $-9.6 \%$ & $-12.6 \%$ \\
\hline Discount per cent & $-23.0 \%$ & $26.6 \%$ \\
\hline Bills per square foot & $43.3 \%$ & $65.1 \%$ \\
\hline Quantity per square foot & $34.9 \%$ & $59.9 \%$ \\
\hline Revenue per square foot & $29.5 \%$ & $44.1 \%$ \\
\hline COGS per square foot & $27.8 \%$ & $44.9 \%$ \\
\hline Eaming per square foot & $27.5 \%$ & $47.6 \%$ \\
\hline Category profit per square foot & $\mathbf{5 0 6 . 7 \%}$ & $\mathbf{3 9 9 . 9 \%}$ \\
\hline Contribution to store bills & $0.2 \%$ & $-5.3 \%$ \\
\hline Contribution to store quantity sale & $0.8 \%$ & $-2.3 \%$ \\
\hline Contribution to store revenue & $6.6 \%$ & $-0.6 \%$ \\
\hline Contribution to store COGS & $5.7 \%$ & $-1.4 \%$ \\
\hline Contribution to store eamings & $5.5 \%$ & $0.3 \%$ \\
\hline
\end{tabular}


Table 9: Post-test percentage change over pre-test across key factors in experimental group for FMCG, Hardlines and Softline category.

\begin{tabular}{|c|c|c|c|c|}
\hline Factors & $\begin{array}{c}\text { Post-Test } \\
\text { Experimental } \\
\text { Group }\end{array}$ & $\begin{array}{c}\text { Post-Test } \\
\text { Experimental } \\
\text { Group } \\
\text { FMCG }\end{array}$ & $\begin{array}{c}\text { Post-Test } \\
\text { Experimental } \\
\text { Group } \\
\text { Hardlines }\end{array}$ & $\begin{array}{c}\text { Post-Test } \\
\text { Experimental } \\
\text { Group } \\
\text { Softines }\end{array}$ \\
\hline Average MRP & $0.4 \%$ & $9.4 \%$ & $-2.5 \%$ & $-0.4 \%$ \\
\hline Average Selling Price & $1.0 \%$ & $9.5 \%$ & $-0.6 \%$ & $-1.3 \%$ \\
\hline Average Cost Price & $3.7 \%$ & $14.2 \%$ & $2.3 \%$ & $-0.7 \%$ \\
\hline Average Earning Vahe & $7.4 \%$ & $14.1 \%$ & $9.2 \%$ & $2.5 \%$ \\
\hline Average Basket Size & $-3.0 \%$ & $-4.3 \%$ & $-6.3 \%$ & $0.9 \%$ \\
\hline Average Transaction Vahe & $-2.5 \%$ & $4.7 \%$ & $-6.9 \%$ & $-0.4 \%$ \\
\hline Discount per cent & $30.6 \%$ & $43.6 \%$ & $31.6 \%$ & $2.6 \%$ \\
\hline Bills persquare foot & $47.2 \%$ & $54.2 \%$ & $37.2 \%$ & $25.9 \%$ \\
\hline Quantity per square foot & $41.8 \%$ & $47.1 \%$ & $28.3 \%$ & $27.2 \%$ \\
\hline Revenue per square foot & $46.6 \%$ & $61.6 \%$ & $28.7 \%$ & $25.9 \%$ \\
\hline COGS per square foot & $52.7 \%$ & $68.7 \%$ & $32.6 \%$ & $26.6 \%$ \\
\hline Eaming per square foot & $49.5 \%$ & $68.1 \%$ & $40.9 \%$ & $30.5 \%$ \\
\hline Profit per square foot & $218.8 \%$ & $154.0 \%$ & $-54.4 \%$ & $89.5 \%$ \\
\hline Contribution to store bills & $28.2 \%$ & $10.3 \%$ & $-1.9 \%$ & $-9.8 \%$ \\
\hline Contribution to store quantity sale & $28.9 \%$ & $8.1 \%$ & $-5.7 \%$ & $-6.4 \%$ \\
\hline Contribution to store revenue & $26.3 \%$ & $18.3 \%$ & $-5.8 \%$ & $-7.7 \%$ \\
\hline Contribution to store COGS & $28.6 \%$ & $19.6 \%$ & $-5.9 \%$ & $-10.0 \%$ \\
\hline Contribution to store eamings & $28.8 \%$ & $19.7 \%$ & $0.4 \%$ & $-6.9 \%$ \\
\hline
\end{tabular}

Statistical analysis demonstrate that, there is an insignificant positive correlation among category bills per square foot, category quantity per square foot, category discount percent, category revenue per square foot, category cost of goods sold (COGS) per square foot and overall store profitability, it indicates a moderate positive correlation among category earning per square foot, category profit per square foot and overall store profitability. We have also found significant positive correlation among bills, quantity, revenue, COGS, earnings, category profit per square foot and overall store profitability across FMCG, Hardlines and Softlines categories except Softline category's correlation between discount percent and overall store profitability being insignificantly negative. All these correlations, determinations and significance levels as shown in table 10,11,12,13,14,15, 16 and 17, in isolation indicate that all the categories behave similarly in relation to their productivity and overall store profitability and fails reveal any important relationship between category mix and overall store profitability. In contrary to statistical results based on productivity the correlations, determinations and significance levels give a completely different perspective when we analyse the relationship among category mix across key factors such as bills, quantity, discount, revenue, COGS and earnings with overall store profitability. For instance, FMCG category contribution to store across key factors is significantly and positively correlated with strong determination to overall store profitability, whereas, Hardlines category contribution has significantly negative correlation and Softline category contribution has insignificantly negative correlation among most of the key factors and overall store profitability. This in a way strongly confirms that the FMCG category contribution to store is important and could possibly determine the overall store profitability.

Table 10: Correlation, regression and significance level irrespective of phase, group and categories. Paired Sampl es Correlations T-Test Regression

\begin{tabular}{|l|l|c|c|c|c|c|c|c|}
\hline Pair & Variables (per square foot values) & R & T & DF & $\begin{array}{c}\text { Sig. } \\
\text { (2-tailed) }\end{array}$ & $\begin{array}{c}\text { Adjusted } \\
\mathbf{R}^{\mathbf{2}}\end{array}$ & F & $\begin{array}{c}\text { ANOVA } \\
\text { Sig. }\end{array}$ \\
\hline Pair 1 & Category Bill \& Store Profit & 0.292 & -10.408 & 287 & 0.000 & 0.082 & 26.715 & 0.000 \\
\hline Pair 2 & Category Quant ity \& Store Profit & 0.252 & -9.859 & 287 & 0.000 & 0.060 & 19.459 & 0.000 \\
\hline Pair3 & Category Discount Per cent \& Store Profit & 0.193 & -9.278 & 287 & 0.000 & 0.034 & 11.030 & 0.001 \\
\hline Pair4 & Category Revenue \& Store Profit & 0.342 & 26.349 & 287 & 0.000 & 0.114 & 37.952 & 0.000 \\
\hline Pair 5 & Category COGS \& Store Profit & 0.328 & 23.739 & 287 & 0.000 & 0.105 & 34.544 & 0.000 \\
\hline Pair 6 & Category Earning \& Store Profit & 0.515 & 39.039 & 287 & 0.000 & 0.262 & 103.001 & 0.000 \\
\hline Pair7 & Category Profit \& Store Profit & 0.480 & 4.998 & 287 & 0.000 & 0.228 & 85.552 & 0.000 \\
\hline
\end{tabular}


Table 11: Correlation, regression and significance level in experimental group irrespective of phase and categories.

\begin{tabular}{|c|c|c|c|c|c|c|c|c|}
\hline \multicolumn{3}{|c|}{ Paired Samples Correlations } & \multicolumn{3}{|c|}{ T-Test } & \multicolumn{3}{|c|}{ Regression } \\
\hline Pair & Variables (per square foot values) & $\mathbf{R}$ & $\mathbf{T}$ & DF & $\begin{array}{c}\text { Sig. } \\
\text { (2-tailed) }\end{array}$ & $\begin{array}{c}\text { Adjusted } \\
\mathbf{R}^{2}\end{array}$ & $\mathbf{F}$ & $\begin{array}{c}\text { ANOVA } \\
\text { Sig. }\end{array}$ \\
\hline Pair 1 & Category Bill \& Store Profit & 0.200 & -16.260 & 143 & 0.000 & 0.330 & 5.897 & 0.016 \\
\hline Pair 2 & Category Quantity \& Store Profit & 0.183 & -15.818 & 143 & 0.000 & 0.027 & 4.942 & 0.028 \\
\hline Pair 3 & Category Discount Percent \& Store Profit & 0.270 & -15.541 & 143 & 0.000 & 0.066 & 11.151 & 0.001 \\
\hline Pair 4 & Categ ory Revenue \& Store Profit & 0.286 & 18.119 & 143 & 0.000 & 0.075 & 12.640 & 0.001 \\
\hline Pair 5 & Category COGS \& Store Profit & 0.280 & 16.200 & 143 & 0.000 & 0.072 & 12.062 & 0.001 \\
\hline Pair 6 & Category Earning \& Store Profit & 0.431 & 23.848 & 143 & 0.000 & 0.180 & 32.333 & 0.000 \\
\hline Pair 7 & Category Profit \& Store Profit & 0.410 & 3.584 & 143 & 0.000 & 0.163 & 28.765 & 0.000 \\
\hline
\end{tabular}

Table 12: Correlation, regression and significance level in control group irrespective of phase and categories.

\begin{tabular}{|c|c|c|c|c|c|c|c|c|}
\hline \multicolumn{3}{|c|}{ Paired Samples Correlations } & \multicolumn{3}{|c|}{ T-Test } & \multicolumn{3}{|c|}{ Regression } \\
\hline Pair & Variables (per square foot values) & $\mathbf{R}$ & $\mathbf{T}$ & DF & $\begin{array}{c}\text { Sig. } \\
\text { (2-tailed) }\end{array}$ & $\begin{array}{c}\text { Adjusted } \\
\mathbf{R}^{2}\end{array}$ & $\mathbf{F}$ & $\begin{array}{c}\text { ANOVA } \\
\text { Sig. }\end{array}$ \\
\hline Pair 1 & Category Bill \& Store Profit & 0.095 & 3.156 & 143 & 0.002 & 0.002 & 1.284 & 0.259 \\
\hline Pair 2 & Category Quantity \& Store $P_{1}$ & 0.084 & 4.301 & 143 & 0.000 & 0. & 1.014 & 0.316 \\
\hline Pair 3 & Category Discount Percen & 0.060 & 5.781 & 143 & 0.000 & -0.003 & 0.512 & 0.475 \\
\hline Pair 4 & Category Revenue \& Store Profit & 0.151 & 21.368 & 143 & 0.000 & 0.016 & 3.300 & 0.071 \\
\hline Pair 5 & Categ ory COGS \& Store Profit & 0.141 & 19.345 & 143 & 0.000 & 0.013 & 2.863 & 0.093 \\
\hline Pair 6 & Category Earning \& Store Profit & 0.267 & 37.186 & 143 & 0.000 & 0.065 & 10.932 & 0.001 \\
\hline Pair 7 & egory Profit \& Store Profit & 0.216 & 3.788 & 143 & 0.000 & 0.040 & 6.957 & 0.009 \\
\hline
\end{tabular}

Table 13: Correlation, regression and significance level in pre-test phase irrespective of groups and categories.

\begin{tabular}{|l|l|c|c|c|c|c|c|c|}
\hline Paired Samples Correlations & & \multicolumn{3}{c|}{ T-Test } & \multicolumn{3}{c|}{ Regression } \\
\hline Pair & Variables (per square foot values) & R & T & DF & $\begin{array}{c}\text { Sig. } \\
\text { (2-tailed) }\end{array}$ & $\begin{array}{c}\text { Adjusted } \\
\mathbf{R}^{\mathbf{2}}\end{array}$ & F & $\begin{array}{c}\text { ANOVA } \\
\text { Sig. }\end{array}$ \\
\hline Pair 1 & Category Bill \& Store Profit & 0.200 & -2.787 & 143 & 0.006 & 0.033 & 5.916 & 0.016 \\
\hline Pair 2 & Category Quantity \& Store Profit & 0.164 & -2.150 & 143 & 0.033 & 0.020 & 3.921 & 0.050 \\
\hline Pair3 & Category Discount Per cent \& Store Profit & 0.005 & -1.520 & 143 & 0.131 & -0.007 & 0.003 & 0.957 \\
\hline Pair4 & Categ ory Revenue \& Store Profit & 0.208 & 22.645 & 143 & 0.000 & 0.037 & 6.437 & 0.012 \\
\hline Pair 5 & Category COGS \& Store Profit & 0.188 & 20.640 & 143 & 0.000 & 0.029 & 5.212 & 0.024 \\
\hline Pair6 & Category Earning \& Store Profit & 0.338 & 36.171 & 143 & 0.000 & 0.108 & 18.340 & 0.000 \\
\hline Pair7 & Category Profit \& Store Profit & 0.370 & 3.292 & 143 & 0.001 & 0.131 & 22.551 & 0.000 \\
\hline
\end{tabular}

Table 14: Correlation, regression and significance level in post-test phase irrespective of groups and categories.

\begin{tabular}{|c|c|c|c|c|c|c|c|c|}
\hline \multicolumn{3}{|c|}{ Paired Samples Correlations } & \multicolumn{3}{|c|}{ T-Test } & \multicolumn{3}{|c|}{ Regression } \\
\hline Pair & Variables (per square foot values) & $\mathbf{R}$ & $\mathbf{T}$ & DF & $\begin{array}{c}\text { Sig. } \\
\text { (2-tailed) }\end{array}$ & $\begin{array}{c}\text { Adjusted } \\
\mathbf{R}^{2}\end{array}$ & $\mathbf{F}$ & $\begin{array}{c}\text { ANOVA } \\
\text { Sig. }\end{array}$ \\
\hline Pair 1 & Categ ory Bill \& Store Profit & 0.270 & -11.928 & 143 & 0.000 & 0.067 & 11.202 & 0.001 \\
\hline Pair 2 & Category Quantity \& Store Profit & 0.239 & -11.560 & 143 & 0.000 & 0.050 & 8.567 & 0.004 \\
\hline Pair 3 & Category Discount Percent \& Store Profit & 0.144 & -11.134 & 143 & 0.000 & 0.014 & 3.009 & 0.085 \\
\hline Pair 4 & Category Revenue \& Store Profit & 0.295 & 17.719 & 143 & 0.000 & 0.081 & 13.579 & 0.000 \\
\hline Pair 5 & Category COGS \& Store Profit & 0.279 & 15.990 & 143 & 0.000 & 0.071 & 11.942 & 0.001 \\
\hline Pair 6 & Categ ory Earning \& Store Profit & 0.456 & 24.845 & 143 & 0.000 & 0.202 & 37.219 & 0.000 \\
\hline Pair 7 & Categ ory Profit \& Store Profit & 0.430 & 3.888 & 143 & 0.000 & 0.179 & 32.189 & 0.000 \\
\hline
\end{tabular}


Table 15: Correlation, regression and significance level in FMCG category irrespective of phases and groups.

\begin{tabular}{|c|c|c|c|c|c|c|c|c|}
\hline \multicolumn{3}{|c|}{ Paired Samples Cor relations } & \multicolumn{3}{|c|}{ T-Test } & \multicolumn{3}{|c|}{ Regression } \\
\hline Pair & Variables (per square foot values) & $\mathbf{R}$ & $\mathbf{T}$ & DF & $\begin{array}{c}\text { Sig. } \\
\text { (2-tailed) }\end{array}$ & $\begin{array}{c}\text { Adjusted } \\
\qquad \mathbf{R}^{2}\end{array}$ & $\mathbf{F}$ & $\begin{array}{c}\text { ANOVA } \\
\text { Sig. }\end{array}$ \\
\hline Pair 1 & Category Bill \& Store Profit & 0.913 & -5.793 & 95 & 0.000 & 0.831 & 468.559 & 0.000 \\
\hline Pair 2 & Category Quantity \& Store Profit & 0.920 & -5.077 & 95 & 0.000 & 0.845 & 518.871 & 0.000 \\
\hline Pair 3 & Category Discount Per cent \& Store Profit & 0.763 & -5.332 & 95 & 0.000 & 0.578 & 131.021 & 0.000 \\
\hline Pair 4 & Category Revenue \& Store Profit & 0.887 & 36.656 & 95 & 0.000 & 0.785 & 347.761 & 0.000 \\
\hline Pair 5 & Category COGS \& Store Profit & 0.881 & 34.528 & 95 & 0.000 & 0.774 & 325.457 & 0.000 \\
\hline Pair 6 & Categ ory Earning \& Store Profit & 0.896 & 42.705 & 95 & 0.000 & 0.801 & 383.286 & 0.000 \\
\hline Pair 7 & Categ ory Profit \& Store Profit & 0.932 & 20.839 & 95 & 0.000 & 0.867 & 620.599 & 0.000 \\
\hline
\end{tabular}

Table 16: Correlation, regression and significance level in Hardlines category irrespective of phases and groups.

\begin{tabular}{|c|c|c|c|c|c|c|c|c|}
\hline \multicolumn{3}{|c|}{ Paired Samples Correlations } & \multicolumn{3}{|c|}{ T-Test } & \multicolumn{3}{|c|}{ Regression } \\
\hline Pair & Variables (per square foot values) & $\mathbf{R}$ & $\mathbf{T}$ & DF & $\begin{array}{c}\text { Sig. } \\
\text { (2-tailed) }\end{array}$ & $\begin{array}{c}\text { Adjusted } \\
\qquad \mathbf{R}^{2}\end{array}$ & $\mathbf{F}$ & $\begin{array}{c}\text { ANOVA } \\
\text { Sig. }\end{array}$ \\
\hline Pair 1 & Categ ory Bill \& Store Profit & 0.905 & -6.110 & 95 & 0.000 & 0.818 & 426.560 & 0.000 \\
\hline Pair 2 & Category Quantity \& Store Profit & 0.909 & -6.060 & 95 & 0.000 & 0.825 & 448.954 & 0.000 \\
\hline Pair 3 & Category Discount Per cent \& Store Profit & 0.566 & -4.964 & 95 & 0.000 & 0.313 & 44.248 & 0.000 \\
\hline Pair 4 & Category Revenue \& Store Profit & 0.852 & 73.584 & 95 & 0.000 & 0.723 & 249.084 & 0.000 \\
\hline Pair 5 & Categ ory COGS \& Store Profit & 0.850 & 70.215 & 95 & 0.000 & 0.719 & 244.674 & 0.000 \\
\hline Pair 6 & Category Earning \& Store Profit & 0.850 & 54.696 & 95 & 0.000 & 0.719 & 244.434 & 0.000 \\
\hline Pair 7 & Category Profit \& Store Profit & 0.876 & -31.355 & 95 & 0.000 & 0.766 & 311.503 & 0.000 \\
\hline
\end{tabular}

Table 17: Correlation, regression and significance level in Softline category irrespective of phases and groups.

\begin{tabular}{|c|c|c|c|c|c|c|c|c|}
\hline \multicolumn{3}{|c|}{ Paired Samples Correlations } & \multicolumn{3}{|c|}{ T-Test } & \multicolumn{3}{|c|}{ Regression } \\
\hline Pair & Variables (per square foot values) & $\mathbf{R}$ & $\mathbf{T}$ & DF & $\begin{array}{c}\text { Sig. } \\
\text { (2-tailed) }\end{array}$ & $\begin{array}{c}\text { Adjusted } \\
\qquad \mathbf{R}^{\mathbf{2}}\end{array}$ & $\mathbf{F}$ & $\begin{array}{c}\text { ANOVA } \\
\text { Sig. }\end{array}$ \\
\hline Pair 1 & Category Bill \& Store Profit & 0.919 & -6.061 & 95 & 0.000 & 0.844 & 514.271 & 0.000 \\
\hline Pair 2 & Category Quantity \& Store Profit & 0.938 & -5.887 & 95 & 0.000 & 0.878 & 684.489 & 0.000 \\
\hline Pair 3 & Category Discount Per cent \& Store & -0.106 & -5.724 & 95 & 0.000 & 0.001 & 1.077 & 0.302 \\
\hline Pair 4 & Categ ory Revenue \& Store Profit & 0.948 & 61.957 & 95 & 0.000 & 0.898 & 834.900 & 0.000 \\
\hline Pair 5 & Categ ory COGS \& Store Profit & 0.950 & 70.022 & 95 & 0.000 & 0.901 & 865.988 & 0.000 \\
\hline Pair 6 & Categ ory Earning \& Store Profit & 0.958 & 122.869 & 95 & 0.000 & 0.918 & 1058.362 & 0.000 \\
\hline Pair 7 & Category Profit \& Store Profit & 0.960 & 18.922 & 95 & 0.000 & 0.920 & 1099.553 & 0.000 \\
\hline
\end{tabular}

Table 18: Correlation, regression and significance level between FMCG category contribution to store across key factors.

\begin{tabular}{|l|l|c|c|c|c|c|c|c|}
\hline Paired Sampl es Correlations & \multicolumn{3}{c}{ T-Test } & \multicolumn{3}{c|}{ Regression } \\
\hline Pair & Variables (category contribution) & R & T & DF & $\begin{array}{c}\text { Sig. } \\
\text { (2-tailed) }\end{array}$ & $\begin{array}{c}\text { Adjusted } \\
\mathbf{R}^{\mathbf{2}}\end{array}$ & F & $\begin{array}{c}\text { ANOVA } \\
\text { Sig. }\end{array}$ \\
\hline Pair 1 & Categ ory Bill \& Store Profit & 0.383 & -3.751 & 143 & 0.000 & 0.141 & 24.383 & 0.000 \\
\hline Pair 2 & Categ ory Quantity \& Store Profit & 0.142 & -3.633 & 143 & 0.000 & 0.013 & 2.941 & 0.089 \\
\hline Pair3 & Category Discount \& Store Profit & 0.660 & -4.742 & 143 & 0.000 & 0.432 & 109.692 & 0.000 \\
\hline Pair4 & Category Revenue \& Store Profit & 0.523 & -5.043 & 143 & 0.000 & 0.269 & 53.593 & 0.000 \\
\hline Pair 5 & Category COGS \& Store Profit & 0.550 & -4.816 & 143 & 0.000 & 0.298 & 61.731 & 0.000 \\
\hline Pair6 & Categ ory Earning \& Store Profit & 0.612 & -5.840 & 143 & 0.000 & 0.370 & 85.157 & 0.000 \\
\hline
\end{tabular}


Table 19: Correlation, regression and significance level between Hardlines category contribution to store across key factors.

\begin{tabular}{|l|l|c|c|c|c|c|c|c|}
\hline Paired Samples Correlations & \multicolumn{3}{c|}{ T-Test } & \multicolumn{3}{c|}{ Regression } \\
\hline Pair & Variables (category contribution) & R & T & DF & $\begin{array}{c}\text { Sig. } \\
\text { (2-tailed) }\end{array}$ & $\begin{array}{c}\text { Adjusted } \\
\mathbf{R}^{2}\end{array}$ & F & $\begin{array}{c}\text { ANOVA } \\
\text { Sig. }\end{array}$ \\
\hline Pair 1 & Category Bill \& Store Profit & -0.343 & -6.269 & 143 & 0.000 & 0.111 & 18.921 & 0.000 \\
\hline Pair 2 & Category Quant ity \& Store Profit & -0.411 & -6.540 & 143 & 0.000 & 0.163 & 28.922 & 0.000 \\
\hline Pair3 & Category Discount \& Store Profit & -0.253 & -3.760 & 143 & 0.000 & 0.057 & 9.678 & 0.002 \\
\hline Pair4 & Category Revenue \& Store Profit & -0.550 & -5.304 & 143 & 0.000 & 0.298 & 61.727 & 0.000 \\
\hline Pair 5 & Category COGS \& Store Profit & -0.503 & -5.252 & 143 & 0.000 & 0.248 & 48.096 & 0.000 \\
\hline Pair6 & Category Earning \& Store Profit & -0.454 & -5.302 & 143 & 0.000 & 0.200 & 36.847 & 0.000 \\
\hline
\end{tabular}

Table 20: Correlation, regression and significance level between Softline category contribution to store across key factors.

\begin{tabular}{|l|l|c|c|c|c|c|c|c|}
\hline Paired Sampl es Correlations & \multicolumn{3}{c}{ T-Test } & \multicolumn{3}{c|}{ Regression } \\
\hline Pair & Variables (category contribution) & R & T & DF & $\begin{array}{c}\text { Sig. } \\
\text { (2-tailed) }\end{array}$ & $\begin{array}{c}\text { Adjusted } \\
\mathbf{R}^{\mathbf{2}}\end{array}$ & F & $\begin{array}{c}\text { ANOVA } \\
\text { Sig. }\end{array}$ \\
\hline Pair 1 & Category Bill \& Store Profit & -0.477 & -4.068 & 143 & 0.000 & 0.222 & 41.916 & 0.000 \\
\hline Pair 2 & Categ ory Quantity \& Store Profit & -0.351 & -3.920 & 143 & 0.000 & 0.117 & 19.943 & 0.000 \\
\hline Pair3 & Category Discount \& Store Profit & -0.355 & -5.566 & 143 & 0.000 & 0.120 & 20.479 & 0.000 \\
\hline Pair4 & Category Revenue \& Store Profit & -0.097 & -3.738 & 143 & 0.000 & 0.002 & 1.338 & 0.249 \\
\hline Pair 5 & Category COGS \& Store Profit & -0.219 & -4.017 & 143 & 0.000 & 0.041 & 7.121 & 0.009 \\
\hline Pair6 & Category Earning \& Store Profit & -0.108 & -2.952 & 143 & 0.004 & 0.005 & 1.676 & 0.198 \\
\hline
\end{tabular}

\section{CONCLUSION:}

Results clearly show that there is a significant and positive correlation with strong determination between contribution of FMCG category and overall store profitability. Hardlines category deliver significant losses to store in spite of higher average transaction values and also being the favourite category of sales personnel. Even though Softline category deliver moderate profit to the store, it is significantly lower in relation to the overall area occupied by the category. It is interesting to find that the FMCG category in spite of occupying the lowest store area, having lowest average selling price products in the assortment and generating lowest average transaction values deliver the highest category profits. FMCG category by its nature is required by consumers more frequently than other categories and if focussed and pushed well, the category is capable of increasing number of repeat consumers thereby enhancing higher consumer retention rate for the store. If retailer considers store's absolute top line value as the key indicator of judging best category for a store, focussing on Hardlines category is ideal. If retailer considers absolute store's profit value as the key indicator of judging best category for a store, pushing FMCG category is ideal. If retailer considers moderate store profits as the key indicator of judging best category for a store, pushing Softline category is ideal. And if the retailer is interested in overall retail performance with consistent growth, sustainable profits and higher consumer retention rate then a rational mix of each of these categories is the ideal solution.

\section{SUGGESTIONS TO BRICK-AND-MORTAR RETAILERS :}

Based on this research outcome, we would like to suggest Brick-and-mortar retailers that, they need to clearly understand the role of every category in relation to target consumer's frequency of needs and merchandise assortment in the offering. Brick-and-mortar retailers need to clearly understand every other retailer's key business objectives behind having categories as part of their merchandise offering which are required by the consumers once in a while compared to other categories. Few may be trying to create perception in consumers mind over their store image, few may be treating such categories as differentiators and few may be concerned only about the top line of the store. What is very important is, how many of such categories which bring down the overall retail profit a retailer can afford to have as part of their merchandise assortment in the long run and what is the magnitude of qualitative benefits 
delivered (if at all) from such categories to the retailer strategically. There is no standard formula to arrive at the best category mix for multi-category retailing and thus, retailers can possibly look at the existing category performance vis-à-vis the key role of a particular category in the overall scheme of their retailing strategy and alter the category mix accordingly. It is imperative to note that, the understanding of the role played by a particular category might not be same among consumers and retailers, what is really important and of significant essence is that, every retailer needs to understand key deliverable of each category which is required to create positive perceptions about the retailer in consumers', competitors and investors' mind.

\section{LIMITATIONS OF RESEARCH :}

The main limitation of this research work is the coverage of various stakeholders viz., categories, consumers and retailer in this study. This might limit the generalizability of the research findings to other set of categories, retailers and consumers studied. The second limitation would be the empirical validation is restricted to one retail format i.e., multi brand and multi category baby care store in India and hence the generalizability of the findings and suggestions to other retail formats. The third limitation would be our ability to carry a true experiment, at best we were able to carry out pre-test post-test control group experimental design. However, it provides significant input regarding the ways to utilise these findings as all the findings have been derived from an experiment spread over a period of six months.

\section{SCOPE FOR FURTHER RESEARCH :}

It is recommended that the experimentation to be applied by researchers and finetune the findings if required for different retailing formats and verticals. Based on the key business objectives for a specific period and specific context, brick-and-mortar retailers can try changing the category mix at their select stores and finetune the same based on real-time findings which can then be implemented across the entire chain of their stores.

\section{REFERENCES:}

[1] Lindquist, J.D. (1974). Meaning of Image: A Survey of Empirical and Hypothetical Evidence. Journal of Retailing, 50(4), 29-38.

[2] Hirschman, E.C., Greenberg, B.\& Robertson, D. (1978). The intermarket reliability of retail image research: an empirical examination. Journal of Retailing, 54(1), 3-12.

[3] Ghosh, A. (1994). Retail Management. Forth Worth, TX: The Dryden Press.

[4] Omar, O. (1999). Retail Marketing. London: Pitman Publishing House.

[5] Mazursky, D. and Jacoby, J. (1986). Exploring the development of store images. Journal of Retailing, 62(2), 145-165.

[6] Lassk, F.G. (2000). Investigating Aspects of Customer Satisfaction at the c-store: The c-store Product Mix and Image. Journal of Professional Services Marketing, 21(2), 15-26.

[7] Osman, M.Z. (1993). A Conceptual Model of Retail Image Influences on Loyalty Patronage Behavior. International Review of Retail Distribution and Consumer Research, 2, 138-48.

[8] Newman, A.J.\& Cullen, P. (2002). Retailing; Environment and Operations. London: Thomson Learning.

[9] Newman, A.J. (2003). Some Manipulable Elements of the Service Setting and Their Impact on Company Image and Reputation. International Journal of New Product Development and Innovation Management, 4(3), 287-304.

[10] Lilien, G. L., Kotler, P., \& Moorthy, K. S. (1995). Marketing Models. Prentice Hall.

[11] Salmon, W. J. (1989). Retailing in the age of execution. Journal of Retailing, 65(3), 368-378. 
[12] Raman, A., DeHoratius, N. and Ton Z. (2001). Execution: the missing link in retail operations. California Management Review, 43(3), 136-142.

[13] Wagner, H.M. (2002). And then there were none. Operations Research. 50(1) 217-227.

[14] James L. Heskett, Earl Sasser, W. \&Leonard Schlesinger (1997). The Service Profit Chain: How Leading Companies Link Profit and Growth to Loyalty, Satisfaction, and Value. New York: The Free Press.

[15] Davis, H. L., \& Silk, A. J. (1972). Interaction and influence processes in personal selling. Sloan Management Review (Pre-1986), 13(2), 59.

[16] Dawson, Lyndon E. Jr, Soper, B., \& Pettijohn, C. E. (1992). The effects of empathy on salesperson effectiveness. Psychology \& Marketing (1986-1998), 9(4), 297.

[17] Sharma, A. (2001). Consumer decision-making, salespeople's adaptive selling and retail performance. Journal of Business Research, 54(2), 125-129.

[18] Pettijohn, C. E., Pettijohn, L. S., \& Taylor, A. J. (2002). The influence of salesperson skill, motivation, and training on the practice of customer-oriented selling. Psychology \& Marketing, 19(9), 743-757.

[19] Davis, D. D. (2008). The influence of salesperson leadership as a customer interaction behavior on sales performance. Nova Southeastern University.

[20] Singh, S., Marinova, D., Singh, J., \& Evans, K. R. (2018). Customer query handling in sales interactions. Journal of the Academy of Marketing Science, 46(5), 837-856.

[21] Ainslie A. and P. Rossi (1998), "Similarities in Choice Behavior Across Multiple Categories," Marketing Science, 17(2): 91-106.

[22] Hoyer, Wayne D. (1984). An Examination of Consumer Decision Making for a Common, Repeat-Purchase Product. Journal of Consumer Research, 11(3), 822-829.

[23] Drèze, Xavier, Stephen Hoch, and Mary E. Purk (1994). Shelf Management and Space Elasticity. Journal of Retailing, 70(4), 301-326.

[24] Chandon, Pierre, Wesley J. Hutchinson, Eric Bradlow, and Scott H. Young (2007). Measuring the Value of Point-of-Purchase Marketing with Commercial Eye-Tracking Data. INSEAD Business School Research Paper No. 2007/22/MKT/ACGRD. 